Evaluation of Commercial Enzyme Immunoassays for the Field Screening of TNT and RDX in Water

Philip G. Thome and Karen F. Myers

December 1997 
Abstract: Water samples from 44 monitoring wells at three military installations were analyzed for the high explosives TNT and RDX using immunoassay test kits. The accuracy and precision of the kit determinations were compared with results obtained using the RP-
HPLC, EPA Method 8330. Most of the kits achieved a $\pm 50 \%$ relative percent difference criterion over $85 \%$ of the time. One of the kits failed this test over half the time. Careful consideration must be given to interferences that may be present and unique for each application.

How to get copies of CRREL technical publications:

Department of Defense personnel and contractors may order reports through the Defense Technical Information Center:

DTIC-BR SUITE 0944

8725 J OHN J KINGMAN RD

FT BELVOIR VA 22060-6218

Telephone 18002253842

E-mail help@dtic.mil

msorders@dtic.mil

WWW http://www.dtic.dla.mil/

All others may order reports through the National Technical Information Service:

NTIS

5285 PORT ROYAL RD

SPRINGFIELD VA 22161

Telephone 17034874650

E-mail $\quad \begin{aligned} & 17034874639 \text { (TDD for } \\ & \text { orders@ntis.fedworld.gov }\end{aligned}$

WWW http://www.fedworld.gov/ntis/ntishome.html

A complete list of all CRREL technical publications is available from:

USACRREL (CECRL-LP)

72 LYME RD

HANOVER NH 03755-1290

Telephone 16036464338

E-mail techpubs@crrel.usace.army.mil

For information on all aspects of the Cold Regions Research and Engineering Laboratory, visit our World Wide Web site: http://www.crrel.usace. army.mil 


\section{Special Report 97-32}

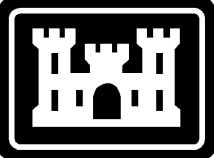

US Army Corps of Engineers

Cold Regions Research \& Engineering Laboratory

\section{Evaluation of Commercial Enzyme Immunoassays for the Field Screening of TNTand RDX in Water}

Philip G. Thome and Karen F. Myers 


\section{PREFACE}

This report was prepared by Philip G. Thorne, Research Physical Scientist, Geological Sciences Division, Research Directorate, U.S. Army Cold Regions Research and Engineering Laboratory (CRREL), Hanover, New Hampshire, and Karen F. Myers, Biologist, Environmental Chemistry Branch, Environmental Engineering Division, U.S. Army Waterways Experiment Station (WES), Vicksburg, Mississippi.

Funding was provided by the U.S. Army Environmental Center, Aberdeen Proving Ground, Maryland, Martin H. Stutz, project monitor, and the U.S. Army Engineer Waterways Experiment Station, Ann B. Strong, project monitor (AF25-AS-001).

The authors gratefully acknowledge Dr. Paul H. Miyares, CRREL, and Thomas A. Ranney, Science and Technology Corporation, for their technical reviews of this manuscript.

This publication reflects the personal views of the authors and does not suggest or reflect the policy, practices, programs, or doctrine of the U.S. Army or the government of the United States. The contents of this report are not to be used for advertising or promotional purposes. Citation of brand names does not constitute an official endorsement or approval of the use of such commercial products. 


\section{CONTENTS}

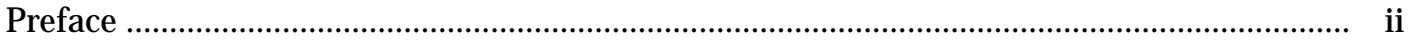

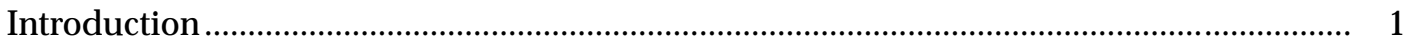

Conventional laboratory analyses ................................................................................. 1

Enzyme immunoassay methods for TNT and RDX …….............................................. 1

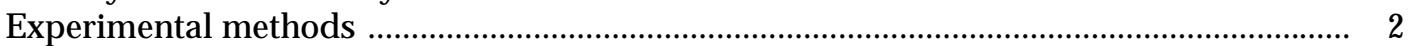

Collection of groundwater samples ........................................................................... 2

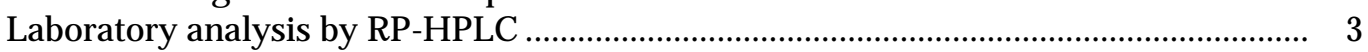

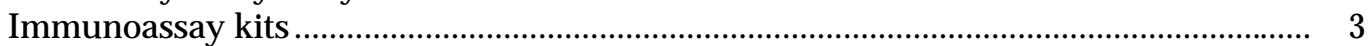

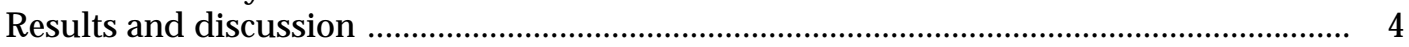

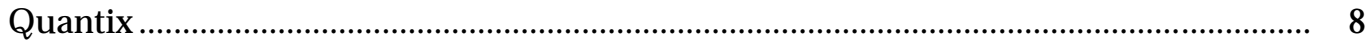

EnviroGard …….................................................................................................. 8

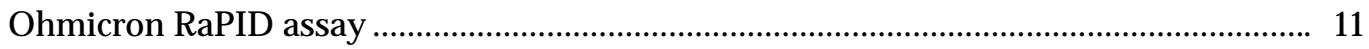

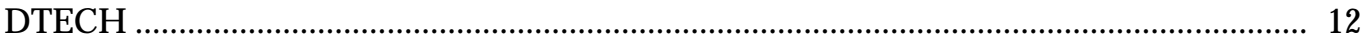

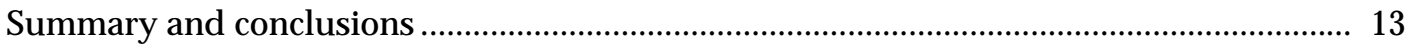

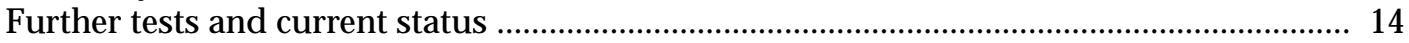

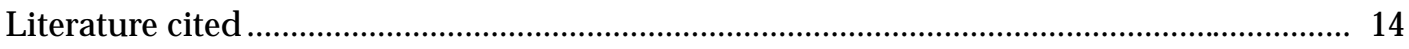

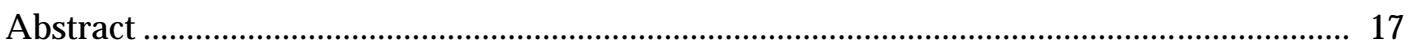

\section{ILLUSTRATIONS}

Figure

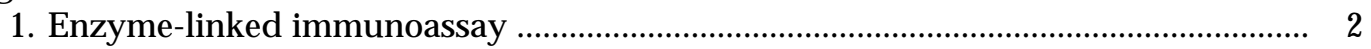

2. Linear ranges of the TNT kits compared with a typical antibody binding curve..... 3

3. TNT concentration vs. absorbance for four sets of standards using the Quantix kit 9

4. RP-HPLC values vs. average Quantix values ............................................................... 9

5. RP-HPLC values vs. all within-range Quantix values ................................................. 9

6. EnviroGard TNT plate kit: five sets of standards ........................................................ 10

7. RP-HPLC values vs. average EnviroGard values .......................................................... 10

8. RP-HPLC values vs. all within-range EnviroGard values ........................................ 10

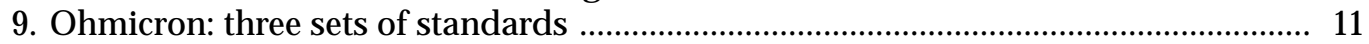

10. RP-HPLC values vs. Ohmicron average values ....................................................... 11

11. RP-HPLC values vs. all within-range Ohmicron values ............................................. 12

12. Serial dilutions of well water compared with standard curve ................................ 12

13. Standard curve produced at WES vs. the DTECH published curve ........................... 13

14. RP-HPLC values vs. DTECH values ........................................................................ 13

\section{TABLES}

Table

1. Cross-reactivities of TNT kits at the $50 \%$ inhibition and detection limit.................. 2

2. Characteristics and performance of test kits .................................................................. 4

3. Samples containing measurable analytes by RP-HPLC …….................................... 5

4. Samples containing no target analytes as determined by RP-HPLC ........................ 8 



\title{
Evaluation of Commercial Enzyme Immunoassays for the Field Screening of TNT and RDX in Water
}

\author{
PHILIP G. THORNE AND KAREN F. MYERS
}

\section{INTRODUCTION}

Contaminated groundwater on and around U.S. military installations is a serious problem. Besides the usual toxic and hazardous materials common to many large industries, the military is a unique source of nitroaromatic and nitramine secondary explosives. The EPA has set low allowable intake limits for these classes of compounds in drinking water (EPA 1988a,b,c, 1989, 1992). To comply with EPA guidelines and to protect the public safety, the U.S. military must identify and remediate sources of contamination.

\section{Conventional laboratory analyses}

The traditional approach used to delineate the extent and degree of explosives contamination has been to analyze monitoring well samples at off-site laboratories using SW846 Method 8330 (EPA 1994). Off-site analysis requires several days' turnaround and delays on-site decision making. Site managers cannot optimize sampling strategies without data on initial samples. In addition, laboratory analyses generally cost over $\$ 200$ per sample. This cost limits the number of samples that can be analyzed, decreasing the spatial resolution of the investigation. A survey of results from 46 military installations (Walsh et al. 1993) showed that approximately two-thirds of the soil samples and three-quarters of the water samples analyzed were not contaminated with secondary explosives or transformation products. Of the samples that were contaminated, $95 \%$ contained TNT (2,4,6-trinitrotoluene) and/or RDX (1,3,5-hexahydro-1,3,5-trinitrotriazine). Significant cost reductions can be achieved if negative samples could be identified without off-site analysis. Furthermore, rapid field determination of the degree of contamination, where present, can assist site managers in prioritizing their sampling efforts.

Field methods for the detection and quantification of TNT and RDX in soil and water have been developed that rely on the colorimetric analysis of highly specific reaction products (Jenkins and Walsh 1992, Jenkins et al. 1994). The detection limits for these tests are $1 \mu \mathrm{g} / \mathrm{g}$ TNT and RDX in soil and $0.9 \mu \mathrm{g} / \mathrm{L} \mathrm{TNT}$ and $3.8 \mu \mathrm{g} / \mathrm{L}$ RDX in water. Several samples an hour can be processed using these methods.

\section{Enzyme immunoassay methods for TNT and RDX}

Enzyme immunoassays are analytical methods based on highly selective binding reactions of antibodies with specific target analytes. Antibodies are proteins produced in response to foreign substances as part of the vertebrate immune response system. Methods developed for small molecules are usually formatted as competitive enzyme-linked immunosorbent assays (ELISAs). In one common form of ELISA (Fig. 1), the target analyte is bound to an enzyme through a spacer molecule to form an enzyme-analyte conjugate. Antibodies are bound onto the surface of a solid, such as the walls of a microtitre well or test tube, or onto small spheres. When a known amount of enzyme-analyte conjugate and sample containing the free target analyte are mixed with the antibodies, they compete with each other for binding sites on the antibodies. Upon the addition of the appropriate substrate, the enzyme catalyzes a reaction that changes a chromogen from colorless to colored. Quantitation is accomplished by comparing color intensity to a standard curve. The 


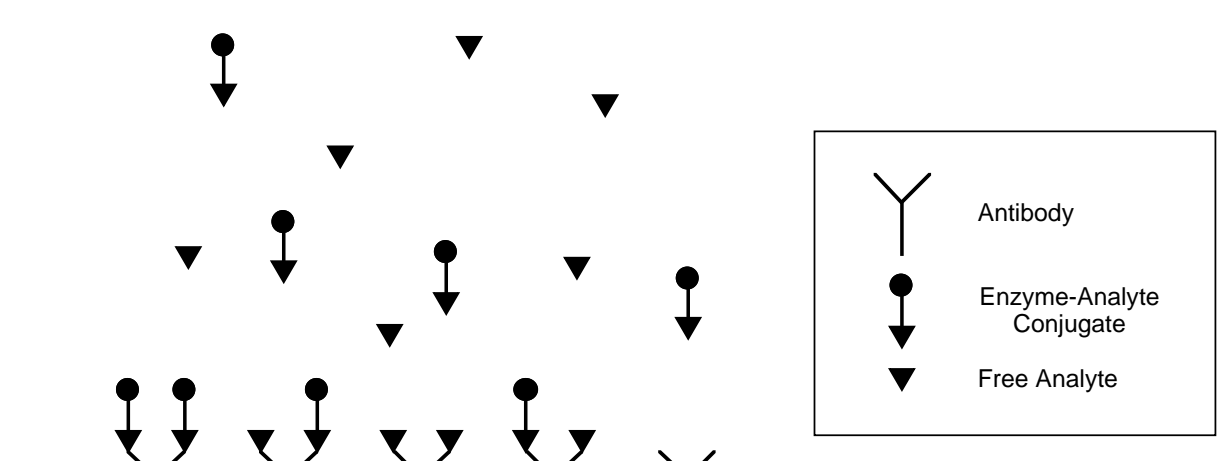

Figure 1. Enzyme-linked immunoassay.

amount of enzyme conjugate retained on the antibodies (i.e., color change) is inversely proportional to the amount of target analyte in the sample (Vanderlaan et al. 1990). In other words, the more intense the color development, the lower the concentration of free analyte in the sample. A less intense color indicates higher concentrations of free analyte.

Many environmental contaminants are small molecules that cannot induce antibody production by themselves. These molecules must be covalently bound to larger carrier proteins in order to stimulate antibody production when injected into an animal. These small molecule-protein conjugates are called haptens. The specificity of an antibody to a target analyte can be influenced by the design of the hapten. This is done by controlling the orientation and spacing between the analyte and carrier protein used to induce the immunological effect. Through careful selection of antibodies it is possible to design immunoassays that can distinguish an analyte from a related family of compounds or a parent compound from its metabolites (Keuchel et al. 1992a,b). In the case of TNT, conjugates could be made by coupling a protein to either a reactive moiety at the 1- position ( e.g., trinitro-sulphonic acid) or at the 2- or 4- position (2- or 4-aminodinitrotoluene). The antibody would then tend to recognize either a trinitro-aromatic or a dinitro-toluene, respectively. The binding of antibodies to nontarget analytes is termed cross reactivity. For molecules with limited numbers of functional groups, specificity becomes more difficult and cross reactivity with other structurally related molecules becomes more likely.

The various schemes that were used by the four manufacturers to produce anti-TNT antibodies resulted in a wide variety of cross-reactive analytes and relative degrees of interference (Table 1). In general, manufacturers emphasize the degree of cross-reactivity that occurs in the middle of the
Table 1. Cross-reactivities of TNT kits at the $50 \%$ inhibition (midrange) and detection limit $(\mu \mathrm{g} / \mathrm{L})$.

\begin{tabular}{lcccc} 
Analyte & $\begin{array}{c}\text { EnviroGard } \\
50 \% / D L\end{array}$ & $\begin{array}{c}\text { Ohmicron } \\
50 \% / D L\end{array}$ & $\begin{array}{c}\text { DTECH } \\
50 \% / D L\end{array}$ & $\begin{array}{c}\text { Quantix } \\
50 \% / D L\end{array}$ \\
\hline TNT & $3 / 0.5$ & $1.44 / 0.07$ & $22 / 5$ & $1.00 / 0.05$ \\
TNB & $95 / 6$ & $2.20 / 0.04$ & $96 / 20$ & $0.47 /^{*}$ \\
2ADNT & $>1000 / 1.6$ & $45 / 0.25$ & $200 / 30$ & $<0.05 /^{*}$ \\
4ADNT & $16 / 0.7$ & $98 / 0.10$ & $>500 />500$ & $0.02 /^{*}$ \\
\hline
\end{tabular}

*Quantix could not supply the DL cross-reactivities.

range of their kits $\left(\mathrm{IC}_{50}\right)$. However, the nature of antibody-hapten interaction produces a curve of concentration vs. binding that is sigmoidal (Fig. 2). Thus, at concentrations close to the detection limits of each kit, the cross reactivities tend to be more pronounced. Environmental degradation products of TNT, such as TNB and amino-DNTs, can produce a significant additional response.

Inaccurate responses in immunoassays can also be caused by compounds that disrupt either antibody binding or enzyme activity. This phenomenon is called interference. In either case, the amount of color development will be less than anticipated-i.e., a false positive response. This is a better choice than a test that would result in false negatives due to environmental interferences. All of the kits tested reduce potential interferences by diluting the sample in an assay solution containing a buffer and bovine serum albumin to reduce the effects of extreme $\mathrm{pH}$ and humic materials (Keuchel et al. 1992c).

DTECH produces the only immunoassay for RDX. Its cross reactivity to HMX is only $3 \%$ at the detection limit. It has no response to nitroaromatics.

\section{EXPERIMENTAL METHODS}

\section{Collection of groundwater samples}

Groundwater samples were collected from 33 monitoring wells at the Naval Surface Warfare 


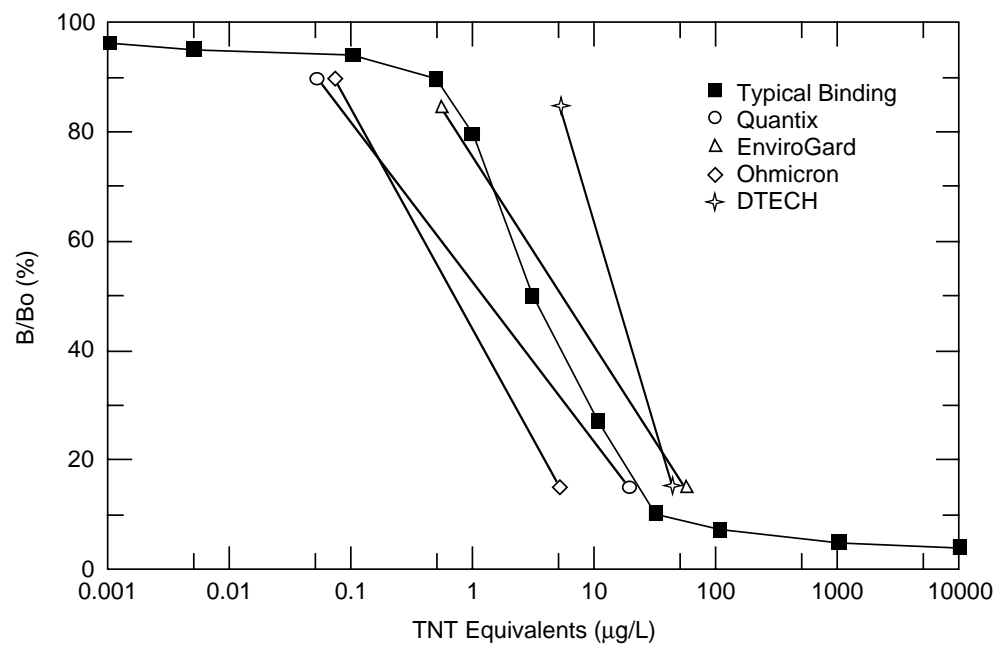

Figure 2. Linear ranges of the TNT kits compared with a typical antibody binding curve. $\% \mathrm{~B} / \mathrm{Bo}=($ Absorbance of sample/Absorbance of negative control) $\times 100$.

Center in Crane, Indiana. Bailers used for collections were rinsed once with isopropyl alcohol and three times with distilled water between samples. Wells were purged with a PVC bailer to a depth midway down the well, allowed to recharge for 2 hours, then sampled with the cleaned Teflon bailers. Samples were collected in 1-liter precleaned, amber glass bottles and were stored and shipped at $4^{\circ} \mathrm{C}\left(39^{\circ} \mathrm{F}\right)$. Samples from five monitoring wells at Umatilla Army Depot Activity, Oregon, and six wells at the U.S. Naval Submarine Base, Bangor, Washington, were supplied by Black and Veatch Waste Science, Tacoma, Washington.

\section{Laboratory analysis by RP-HPLC}

Water samples were analyzed as described in SW846 Method 8330 (EPA 1994). At WES, samples were diluted 1:1 with methanol, and aliquots of $50 \mu \mathrm{L}$ were injected on two RP-HPLC systems (Millipore/Waters Chromatography Division, Milford, Mass.). The primary system consisted of a Waters model 600E MS System Controller, a 712 WISP Auto Injector, a 486 UV Variable-Wavelength Detector monitored at $254 \mathrm{~nm}$, and a Maxima 820 chromatography workstation. The columns used were Supelco $25 \mathrm{~cm} \times 4.6 \mathrm{~mm} \mathrm{LC}-18$ for the primary separation and $25 \mathrm{~cm} \times 4.6 \mathrm{~mm}$ LC-CN for the confirmation separation. Analytes were eluted with 1:1 methanol/water at flow rates of $1.0 \mathrm{~mL} / \mathrm{min}$ and $1.2 \mathrm{~mL} / \mathrm{min}$, respectively. Water samples were also concentrated by salting-out solvent extraction (SOE) and analyzed on the same systems. Stored samples were analyzed at CRREL, using identical columns and $10-\mu \mathrm{L}$ aliquots of 1:1 methanol-diluted samples. The chromatography system consisted of a Spectra Physics 8810 pump, 8875 autosampler, and 8490 detector at $254 \mathrm{~nm}$. Peak heights were recorded with a Hewlett-Packard 3396 Integrator.

\section{Immunoassay kits}

Kits from four manufacturers were tested for this report. Although each kit was based on the same principals of a competitive immunoassay, each kit was formatted differently and had widely different dynamic ranges (Table 2).

The EnviroGard (Millipore, Medford, Mass.) and Quantix (Idetek, Sunnyvale, Calif.) kits are intended as quantitative laboratory assays, although they can be implemented in field situations with battery-powered spectrophotometers. The antibodies were immobilized onto the surfaces of 96well microtitre strip-plates. Duplicate water samples or standards and enzyme-conjugated TNT were diluted in an assay buffer in the wells of the plate. These were incubated at room temperature for either 60 minutes in the EnviroGard kit or 30 minutes in the Quantix kit. The wells were then rinsed to remove unbound free and conjugated TNT. The substrate and chromogen were added and a blue color allowed to develop for $30 \mathrm{~min}$ utes. An acid solution was added to stop the enzyme reaction and change the color of the chromogen from blue to yellow. The absorbance was measured with a spectrophotometer designed to read microtitre strips. Concentrations of analytes were calculated by semi-log regression 
Table 2. Characteristics and performance of test kits.

\begin{tabular}{lccccccc} 
Kit & $\begin{array}{c}\text { Initial } \\
\text { cost }(\$)\end{array}$ & Format & $\begin{array}{c}\text { Range } \\
(\mu g / L)\end{array}$ & $\begin{array}{c}\text { Kit } \\
\text { cost }(\$)\end{array}$ & $\begin{array}{c}\text { Cost/day } \\
(10 \text { samples })\end{array}$ & $\begin{array}{c}\% \text { false } \\
\text { neg/pos }\end{array}$ & $\begin{array}{c}\text { Accuracy } \\
\%<R P D=50\end{array}$ \\
\hline Quantix & $\begin{array}{c}6300 \\
\text { (4000 for govt.) }\end{array}$ & $\begin{array}{c}96-\text {-well } \\
\text { strips }\end{array}$ & $0.05-20$ & 840 & 210 & $0 / 0$ & 100 \\
EnviroGard & 2130 & $\begin{array}{c}96-\text {-well } \\
\text { strips }\end{array}$ & $0.5-50$ & 387 & 97 & $0 / 6$ & 86 \\
Ohmicron & 4435 & $\begin{array}{c}\text { Test } \\
\text { tubes }\end{array}$ & $0.07-5.0$ & 210 & 168 & $0 / 0$ & 85 \\
DTECH TNT & 0 & Cups & $5-45$ & 100 & 250 & $0 / 30$ & 58 \\
DTECH RDX & 0 & Cups & $5-45$ & 100 & 250 & $24 / 18$ & 32 \\
\hline
\end{tabular}

against the standards by programs within the Quantix-supplied reader.

The RaPID kit (Ohmicron, Newtown, Pa.) is a quantitative laboratory assay that can be utilized in the field with a battery-powered spectrophotometer. Antibodies were immobilized on plastic beads containing a ferrous metal particle. Duplicate samples or standards, TNT conjugate, antibody beads, and diluent were incubated in 12$\mathrm{mm} \times 75$-mm plastic test tubes for 15 minutes. The tubes were then placed in a rack that contained strong magnets. The particles were drawn to the sides of the tube where they remained when the liquid contents of the tube were poured off and the particles rinsed. Substrate and chromagen was then added and the color developed for $20 \mathrm{~min}$ utes. Absorbances were measured and concentrations calculated against the standards by the Ohmicron-supplied spectrophotometer.

The DTECH TNT and RDX kits (EM Science, Gibbstown, N.J.) are semiquantitative field tests that require no electronic equipment. Antibodies were immobilized on plastic beads contained in small vials. For each test, a sample diluted in assay buffer containing TNT conjugate was added to one vial and buffer containing only the TNT conjugate was added to a second vial. These incubated for 2 minutes. Then the vials were swirled to suspend the particles and the contents were poured into side-by-side wells in the top of a cup. The bottom of each well was constructed of porous material that allowed the liquid contents of the vial to drain into absorbent material in the cup while retaining the antibody-coated beads. The beads were rinsed in place and substrate was added along with a chromogen that produced a blue precipitate upon activation by the conjugated enzyme. Concentration ranges were determined by comparing the color of the sample well to the color on a test card after the color of the reference well had reached a sufficient intensity to match the reference color on the card. The time required for development depends on temperature and was predicted to be around 10 minutes. Alternatively, a differential reflectometer supplied by DTECH could be used to quantify the inhibition due to TNT or RDX in the sample compared with the reference. The resulting number is then converted to a concentration range based on a calibration table supplied with the kit.

\section{RESULTS AND DISCUSSION}

Results from the RP-HPLC analyses showed that 19 of the 33 Crane wells were contaminated with nitramine and nitroaromatic explosives and their environmental transformation products (Tables 3 and 4). The samples that were stored at CRREL for one month were only analyzed for TNT and its transformation products by direct injection. Some of the samples had concentrations that dropped below the detection limit of this method. Other samples showed significant transformation of TNT. All of the Umatilla and Bangor wells had detectable levels of nitramines and nitroaromatics.

There are two ways of evaluating the TNT results from each kit. One way assesses the ability of the kits to determine correctly if there is contamination above the EPA's health advisory limit of $2 \mu \mathrm{g} / \mathrm{L}$ (EPA 1989). The DTECH kit has a detection limit above that and could not be assessed by this criterion. All of the other TNT kits were successful in indicating the presence of TNT when it was there at greater than $2 \mu \mathrm{g} / \mathrm{L}$. There were no false negatives. They could be used in remediation projects to indicate when contamination levels dropped below the detection limit of the kit.

Another way to assess kit performance is to measure accuracy using the relative percent difference (RPD), where 
Table 3. Samples containing measurable analytes $(\mu \mathrm{g} / \mathrm{L})$ by RP-HPLC. False negatives and false positives are in bold. Stored samples were analyzed at CRREL.

\begin{tabular}{|c|c|c|c|c|c|c|c|c|c|c|c|c|}
\hline Well no. & $p H$ & Type & $H M X$ & $R D X$ & TNB & $D N B$ & $D N A$ & TNT & $\Sigma T N T^{*}$ & DNT & $2 A D N T$ & $4 A D N T$ \\
\hline $\begin{array}{l}\text { CRANE } \\
615\end{array}$ & 7.1 & $\begin{array}{l}\text { DIR } \\
\text { SOE } \\
\text { DTECH } \\
\text { OHM } \\
\text { EG }\end{array}$ & $\begin{array}{c}<0.2 \mathrm{al} \\
1.45\end{array}$ & $\begin{array}{c}\text { Inalytes } \\
2.45\end{array}$ & $\begin{array}{c}5-15 \\
0.74 \\
<0.5\end{array}$ & $\begin{array}{l}0.79 \\
0.53\end{array}$ & & $\begin{array}{c}0.47 \\
5-15\end{array}$ & 0.52 & & 0.36 & 0.32 \\
\hline 616 & 7.1 & $\begin{array}{l}\text { DIR } \\
\text { SOE } \\
\text { DTECH } \\
\text { OHM } \\
\text { EG } \\
\text { storedDIR } \\
\text { EG } \\
\text { QTX }\end{array}$ & $\begin{array}{l}94.0 \\
54.2\end{array}$ & $\begin{array}{c}79.0 \\
63.8 \\
25-45\end{array}$ & & & & $\begin{array}{c}0.26 \\
<5 \\
1.58 \\
2.9 \\
<2.0 \\
2.5 \\
<0.05\end{array}$ & $\begin{array}{l}0.33 \\
0.79 \\
1.07 \\
0.60\end{array}$ & & 3.08 & $\begin{array}{r}1.36 \\
<2.0\end{array}$ \\
\hline 617 & 6.8 & $\begin{array}{l}\text { DIR } \\
\text { SOE } \\
\text { DTECH } \\
\text { OHM } \\
\text { EG } \\
\text { storedDIR } \\
\text { EG } \\
\text { QTX }\end{array}$ & $\begin{array}{l}93.0 \\
85.7\end{array}$ & $\begin{array}{c}91.0 \\
75.3 \\
25-45\end{array}$ & & & 0.22 & $\begin{array}{c}0.19 \\
<5 \\
0.6 \\
2.0 \\
<2.0 \\
2.0 \\
<0.05\end{array}$ & $\begin{array}{l}0.08 \\
0.45 \\
0.65 \\
0.68\end{array}$ & & $\begin{array}{r}2.43 \\
<2.0\end{array}$ & $\begin{array}{r}1.31 \\
<2.0\end{array}$ \\
\hline 618 & 6.8 & $\begin{array}{l}\text { DIR } \\
\text { SOE } \\
\text { DTECH } \\
\text { OHM } \\
\text { EG } \\
\text { storedDIR } \\
\text { EG } \\
\text { QTX }\end{array}$ & $\begin{array}{l}45.0 \\
45.7\end{array}$ & $\begin{array}{l}14 \\
16.4 \\
5-15\end{array}$ & & & 0.17 & & $\begin{aligned} &<5 \\
& 0.36 \\
& 4.5 \\
&<2.0 \\
& 3.1 \\
&<0.05\end{aligned}$ & $\begin{array}{l}0.42 \\
0.47 \\
0.24\end{array}$ & $\begin{array}{r}2.18 \\
<2.0\end{array}$ & $\begin{array}{r}1.21 \\
<2.0\end{array}$ \\
\hline $\begin{array}{l}618 \\
\text { Dupl }\end{array}$ & 7.0 & $\begin{array}{l}\text { DIR } \\
\text { SOE } \\
\text { DTECH } \\
\text { OHM }\end{array}$ & $\begin{array}{r}45.0 \\
45.5 \\
5-15\end{array}$ & $\begin{array}{l}11.0 \\
14.1\end{array}$ & & & 0.09 & & $\begin{array}{l}<5 \\
0.32\end{array}$ & $\begin{array}{l}0.27 \\
0.45\end{array}$ & 1.82 & 1.08 \\
\hline 619 & 6.9 & $\begin{array}{l}\text { DIR } \\
\text { SOE } \\
\text { DTECH } \\
\text { OHM } \\
\text { EG }\end{array}$ & $\begin{array}{c}<0.2 \mathrm{al} \\
0.76\end{array}$ & $\begin{array}{c}\text { Inalytes } \\
\quad 5.77 \\
<5\end{array}$ & & & & & $\begin{array}{l}<5 \\
<0.07 \\
<0.5\end{array}$ & $\begin{aligned} & 0.02 \\
< & 0.07 \\
< & 0.5\end{aligned}$ & 0.13 & \\
\hline 622 & 7.2 & $\begin{array}{l}\text { DIR } \\
\text { SOE } \\
\text { DTECH15 } \\
\text { OHM } \\
\text { EG }\end{array}$ & $\begin{array}{c}134 \\
75.4 \\
0-250\end{array}$ & $\begin{array}{l}365 \\
202\end{array}$ & & & & & $\begin{array}{c}0.98 \\
<5 \\
4.5 \\
1.4\end{array}$ & $\begin{array}{l}2.18 \\
1.63 \\
1.67\end{array}$ & 8.12 & 1.80 \\
\hline 623 & 7.0 & $\begin{array}{l}\text { DIR } \\
\text { SOE } \\
\text { DTECH } \\
\text { OHM } \\
\text { EG }\end{array}$ & $\begin{array}{c}<0.2 \mathrm{al} \\
0.61\end{array}$ & $\begin{array}{l}\text { Inalytes } \\
10.9 \\
<5\end{array}$ & & & & & $\begin{array}{l}<5 \\
<0.07 \\
<0.5\end{array}$ & & & \\
\hline 624 & 7.1 & $\begin{array}{l}\text { DIR } \\
\text { SOE } \\
\text { DTECH } \\
\text { OHM } \\
\text { EG }\end{array}$ & $\begin{array}{l}25.0 \\
30.2\end{array}$ & $\begin{array}{l}13.0 \\
12.1 \\
5-15\end{array}$ & & & & & $\begin{array}{c}<5 \\
0.1\end{array}$ & & & \\
\hline
\end{tabular}

* $\Sigma \mathrm{TNT}=$ the sum of TNT equivalents based on the particular cross reactivities for each kit.

Note: $\mathrm{DIR}=$ direct injection, $\mathrm{SOE}=$ salting-out extraction, $\mathrm{OHM}=$ Ohmicron, $\mathrm{EG}=$ EnviroGard, $\mathrm{QTX}=$ Quantix, Dupl. = duplicate. 
Table 3 (cont'd). Samples containing measurable analytes $(\mu \mathrm{g} / \mathrm{L})$ by RP-HPLC.

\begin{tabular}{|c|c|c|c|c|c|c|c|c|c|c|c|c|}
\hline Well no. & $p H$ & Type & $H M X$ & $R D X$ & $T N B$ & $D N B$ & $D N A$ & TNT & $\Sigma T N T$ & DNT & $2 A D N T$ & $4 A D N T$ \\
\hline 646 & - & $\begin{array}{l}\text { DIR <0. } \\
\text { SOE } \\
\text { DTECH } \\
\text { OHM } \\
\text { EG }\end{array}$ & $\begin{array}{l}2 \text { all anal } \\
1.05\end{array}$ & $\begin{array}{l}\text { ytes } \\
6.17 \\
5-15\end{array}$ & & & & $\begin{array}{r}<5 \\
0.4 \\
<0.5\end{array}$ & $\begin{array}{l}0.13 \\
0.21 \\
0.09\end{array}$ & & 0.71 & 0.33 \\
\hline 651 & - & $\begin{array}{l}\text { DIR <0. } \\
\text { SOE } \\
\text { DTECH } \\
\text { OHM } \\
\text { EG }\end{array}$ & $\begin{array}{c}2 \text { all anal } \\
0.33\end{array}$ & $\begin{array}{c}\text { ytes } \\
\quad 7.12 \\
<5\end{array}$ & & & & $\begin{array}{l}<5 \\
0.44 \\
<0.5\end{array}$ & & & & \\
\hline 713 & 6.4 & $\begin{array}{l}\text { DIR } \\
\text { SOE } \\
\text { DTECH } \\
\text { OHM } \\
\text { EG }\end{array}$ & & $\begin{array}{c}13.0 \\
5.98 \\
<5\end{array}$ & & & & $\begin{array}{c}\mathbf{5 - 1 5} \\
0.08 \\
<0.5\end{array}$ & & & & \\
\hline 717 & 6.2 & $\begin{array}{l}\text { DIR } \\
\text { SOE } \\
\text { DTECH } \\
\text { OHM } \\
\text { EG }\end{array}$ & $<.58$ & $\begin{array}{l}40.0 \\
28.7\end{array}$ & & & 0.04 & $\begin{array}{c}<5 \\
<0.07 \\
0.7\end{array}$ & $\begin{array}{l}0.06 \\
0.12 \\
0.04\end{array}$ & 0.39 & 0.13 & \\
\hline 725 & 6.0 & $\begin{array}{l}\text { DIR } \\
\text { SOE } \\
\text { DTECH } \\
\text { OHM } \\
\text { EG }\end{array}$ & $\begin{array}{l}165 \\
141\end{array}$ & $\begin{array}{l}58.0 \\
39.1 \\
<5\end{array}$ & & & 0.79 & $\begin{array}{c}0.96 \\
5-15 \\
4.1 \\
22\end{array}$ & $\begin{array}{l}1.7 \\
1.54 \\
1.4\end{array}$ & & $\begin{array}{l}9.00 \\
8.5\end{array}$ & $\begin{array}{l}7.00 \\
5.62\end{array}$ \\
\hline 727 & 6.4 & $\begin{array}{l}\text { DIR } \\
\text { SOE } \\
\text { DTECH } \\
\text { OHM } \\
\text { EG } \\
\text { storedDIR } \\
\text { EG } \\
\text { QTX }\end{array}$ & $\begin{array}{l}173 \\
172 \\
\end{array}$ & $\begin{array}{l}76.0 \\
69.5 \\
<5\end{array}$ & & & 2.59 & $\begin{array}{l}17.0 \\
23.1 \\
15-25 \\
29.2 \\
51 \\
18.0 \\
53 \\
11\end{array}$ & $\begin{array}{l} \\
29 \\
22.4 \\
27.8 \\
\\
\\
25.5 \\
18.8\end{array}$ & 1.2 & $\begin{array}{l}59.0 \\
65.2\end{array}$ & $\begin{array}{l}54.0 \\
56.4 \\
\\
30.0\end{array}$ \\
\hline 731 & 6.4 & $\begin{array}{l}\text { DIR } \\
\text { SOE } \\
\text { DTECH } \\
\text { OHM } \\
\text { EG } \\
\text { storedDIR } \\
\text { EG } \\
\text { QTX }\end{array}$ & $\begin{array}{l}252 \\
227\end{array}$ & $\begin{array}{r}157 \\
132 \\
<5\end{array}$ & $\begin{array}{r}5.00 \\
6.62 \\
\\
13.7\end{array}$ & & 15.6 & $\begin{array}{c}110 \\
102 \\
150-250 \\
176 \\
165 \\
115 \\
145 \\
114\end{array}$ & $\begin{array}{l}118 \\
115 \\
123 \\
\\
118 \\
111\end{array}$ & & $\begin{array}{l}47.0 \\
42.6\end{array}$ & $\begin{array}{l}65.0 \\
56.5 \\
\\
50.0\end{array}$ \\
\hline 733 & 6.5 & $\begin{array}{l}\text { DIR } \\
\text { SOE } \\
\text { DTECH } \\
\text { OHM } \\
\text { EG }\end{array}$ & $\begin{array}{l}218 \\
201\end{array}$ & $\begin{array}{l}40.0 \\
35.9 \\
5-15\end{array}$ & & & & $\begin{array}{l}<5 \\
0.28 \\
2.0\end{array}$ & $\begin{array}{l}0.29 \\
0.60 \\
0.38\end{array}$ & & 2.2 & 1.9 \\
\hline 737 & 6.1 & $\begin{array}{l}\text { DIR <0. } \\
\text { SOE } \\
\text { DTECH } \\
\text { OHM } \\
\text { EG }\end{array}$ & $\begin{array}{c}2 \text { all ana } \\
2.15\end{array}$ & $\begin{array}{c}\text { ytes } \\
\qquad \begin{array}{c}7.54 \\
<5\end{array}\end{array}$ & & & & $\begin{array}{l}\mathbf{5 - 1 5} \\
<0.07 \\
<0.5\end{array}$ & & & & \\
\hline 743 & 4.5 & $\begin{array}{l}\text { DIR } \\
\text { SOE } \\
\text { DTECH } \\
\text { OHM } \\
\text { EG } \\
\text { storedDIR } \\
\text { EG } \\
\text { QTX }\end{array}$ & $\begin{array}{c}112 \\
82.8\end{array}$ & $\begin{array}{c}608 \\
429 \\
125-225\end{array}$ & $\begin{array}{l}8.00 \\
4.45\end{array}$ & 0.79 & & $\begin{array}{c}180 \\
137 \\
750-1250 \\
270 \\
206 \\
179 \\
176 \\
124\end{array}$ & $\begin{array}{l} \\
182 \\
185 \\
182 \\
\\
181 \\
180\end{array}$ & & $\begin{array}{c}10.0 \\
7.71\end{array}$ & $\begin{array}{l}8.00 \\
6.20\end{array}$ \\
\hline
\end{tabular}


Table 3 (cont'd).

\begin{tabular}{|c|c|c|c|c|c|c|c|c|c|c|c|c|}
\hline Well no. & $p H$ & Type & $H M X$ & $R D X$ & $T N B$ & $D N B$ & DNA & TNT & $\Sigma T N T$ & DNT & $2 A D N T$ & $4 A D N T$ \\
\hline 745 & 5.8 & $\begin{array}{l}\text { DIR } \\
\text { SOE } \\
\text { DTECH } \\
\text { OHM } \\
\text { EG } \\
\text { storedDIR } \\
\text { EG } \\
\text { QTX }\end{array}$ & $\begin{array}{l}325 \\
290\end{array}$ & $\begin{array}{c}87.5 \\
25-75\end{array}$ & 6.31 & & 8.3 & $\begin{array}{c}14.0 \\
13.9 \\
25-45 \\
34.5 \\
114 \\
7.6 \\
82 \\
11.6\end{array}$ & $\begin{array}{c}22.7 \\
18.7 \\
22 \\
\\
18 \\
8.0\end{array}$ & & $\begin{array}{l}51.0 \\
42.3\end{array}$ & $\begin{array}{l}40.0 \\
33.5\end{array}$ \\
\hline $2 \mathrm{ppb} \mathrm{Bl}$ & nk sp & $\begin{array}{l}\text { ke } \\
\text { DTECH } \\
\text { OHM } \\
\text { EG }\end{array}$ & & 5-15 & & & & $\begin{array}{c}5-15 \\
4.30 \\
2.3\end{array}$ & & & & \\
\hline $\begin{array}{l}\text { UMATI } \\
4-1\end{array}$ & & $\begin{array}{l}\text { DIR } \\
\text { OHM }\end{array}$ & 1290 & 2370 & 241 & & & 2685 & $\begin{array}{l}1993 \\
2165\end{array}$ & & & \\
\hline 4-18 & & $\begin{array}{l}\text { DIR } \\
\text { OHM }\end{array}$ & 1850 & 1880 & 316 & & & 3620 & $\begin{array}{l}3627 \\
3848\end{array}$ & & & \\
\hline 4-P4 & & $\begin{array}{l}\text { DIR } \\
\text { OHM }\end{array}$ & 81 & 4500 & 41 & & & 111 & $\begin{array}{r}2 \\
28\end{array}$ & & & \\
\hline $4-103$ & & $\begin{array}{l}\text { DIR } \\
\text { OHM }\end{array}$ & 51 & 1520 & 4.2 & & & 6.9 & $\begin{array}{l}2 \\
5\end{array}$ & & & \\
\hline $4-7$ & & $\begin{array}{l}\text { DIR } \\
\text { OHM }\end{array}$ & 219 & & 0.3 & & & 1.44 & 0.2 & & & \\
\hline $\begin{array}{l}\text { BANGC } \\
\text { BEW1 }\end{array}$ & & $\begin{array}{l}\text { DIR } \\
\text { OHM }\end{array}$ & 151 & 539 & 151 & & & $\begin{array}{l}315 \\
481\end{array}$ & 413 & & & \\
\hline BEW2 & & $\begin{array}{l}\text { DIR } \\
\text { OHM }\end{array}$ & 35 & 678 & 13 & & & $\begin{array}{l}30 \\
76\end{array}$ & 38 & & & \\
\hline BEW4 & & $\begin{array}{l}\text { DIR } \\
\text { OHM }\end{array}$ & 39 & 2.7 & & & & 0.56 & 1.7 & & & \\
\hline PRE1-6 & & $\begin{array}{l}\text { DIR } \\
\text { OHM }\end{array}$ & 31 & 285 & 23 & & & $\begin{array}{r}46 \\
159 \\
\end{array}$ & 61 & & & \\
\hline
\end{tabular}

$$
\mathrm{RPD}=\frac{(\text { kit value }- \text { labvalue })}{(\text { kit value }+ \text { labvalue }) / 2} \times 100
$$

A $\pm 50 \%$ RPD is the commonly used control limit for field kits. The EnviroGard, Quantix, and Ohmicron kits met this criterion more than $85 \%$ of the time. The DTECH kits failed this criterion over half the time. Positive results require confirmation by laboratory analysis. In on-site assessment, false positives add to the cost of laboratory assays. In remediation activities, false positives could become quite expensive if they triggered an additional treatment step (e.g., replacing a purification cartridge or extending a composting period or excavating an additional lift of soil). For the discussion of results that follows, a false positive is defined as an erroneously high value for TNT contamination above the EPA 1989 Health Advisory of $2 \mu \mathrm{g} / \mathrm{L}$.
The RDX kit produced very poor results for these samples. It failed to detect RDX in eight of the samples that contained RDX above the EPA Health Advisory limit of $2 \mu \mathrm{g} / \mathrm{L}$ (EPA 1988a). It also produced six false positives.

The cost of the kits requiring daily calibration varies depending on the number of samples analyzed per day. The more samples that can be analyzed, the better. For this investigation of monitoring wells at NSWC, 33 samples were generated in 3 days. For cost comparison estimates, ten sample analyses per day was chosen. The strip-plate kits have a unique problem that becomes apparent because of their design. There are 96 assay wells arranged in long strips containing either 12 (EnviroGard) or 8 (Quantix) wells each. All wells in a strip must be used. Unused well-strips cannot be saved for future use. Thus 10 samples, one standard, and one blank run in duplicate (24 
Table 4. Samples containing no target analytes $(<0.2 \mu \mathrm{g} / \mathrm{L})$ as determined by RP-HPLC. False positives listed in bold.

\begin{tabular}{|c|c|c|c|c|}
\hline Well no. & $p H$ & & $R D X$ & TNT \\
\hline 625 & - & $\begin{array}{l}\text { DTECH } \\
\text { OHM } \\
\text { EG }\end{array}$ & $<5$ & $\begin{array}{l}<5 \\
<0.07 \\
<0.5\end{array}$ \\
\hline 627 & - & $\begin{array}{l}\text { DTECH } \\
\text { OHM } \\
\text { EG }\end{array}$ & $<5$ & $\begin{array}{l}<5 \\
<0.07 \\
<0.5\end{array}$ \\
\hline 715 & 6.6 & $\begin{array}{l}\text { DTECH } \\
\text { OHM } \\
\text { EG }\end{array}$ & $5-15$ & $\begin{array}{l}<5 \\
<0.07 \\
<0.5\end{array}$ \\
\hline 719 & 4.5 & $\begin{array}{l}\text { DTECH } \\
\text { OHM } \\
\text { EG }\end{array}$ & $<5$ & $\begin{array}{l}<5 \\
<0.07 \\
<0.5\end{array}$ \\
\hline 729 & 6.1 & $\begin{array}{l}\text { DTECH } \\
\text { OHM } \\
\text { EG }\end{array}$ & $<5$ & $\begin{array}{l}5-15 \\
<0.07 \\
<0.5\end{array}$ \\
\hline 735 & 5.9 & $\begin{array}{l}\text { DTECH } \\
\text { OHM } \\
\text { EG }\end{array}$ & $5-15$ & $\begin{array}{c}5-15 \\
<0.07 \\
1.2\end{array}$ \\
\hline 739 & 5.8 & $\begin{array}{l}\text { DTECH } \\
\text { OHM } \\
\text { EG }\end{array}$ & $15-25$ & $\begin{array}{l}\mathbf{5 - 1 5} \\
<0.07 \\
<0.5\end{array}$ \\
\hline 741 & 3.7 & $\begin{array}{l}\text { DTECH } \\
\text { OHM } \\
\text { EG }\end{array}$ & $<5$ & $\begin{array}{c}\mathbf{5 - 1 5} \\
<0.07 \\
0.7\end{array}$ \\
\hline
\end{tabular}

wells) require two EnviroGard strips or three Quantix strips. An eleventh sample would require the use of an additional strip.

These kits have other potential uses, and other problems, that are best discussed with reference to each kit's characteristics.

\section{Quantix}

The Quantix kit is primarily intended as a quantitative laboratory assay. It is the most expensive and complicated of the four kits. A strip-reader, an orbital plate-shaker for incubations, a plate-washer, and wash solution were recommended to achieve the best results. Five standards and a negative control were supplied for calibrations. The Quantix strip-reader has a program that calculates results based on a five-point calibration. The linearity and reproducibility of four standard curves was excellent, with a relative standard deviation of slopes equal to $4.4 \%$ (Fig. 3). However, a plot of the accuracy of the determinations (Fig. 4) reveals an underestimation of concentrations compared with the RP-HPLC determinations. Two of the samples required a 1:100 dilution with reagent-grade water to fall within the range of the test. If the results of the diluted samples are com-

\begin{tabular}{|c|c|c|c|c|}
\hline Well no. & $p H$ & & $R D X$ & TNT \\
\hline \multirow[t]{4}{*}{766} & 5.7 & DTECH & $<5$ & $5-15$ \\
\hline & & $\mathrm{OHM}$ & & $<0.07$ \\
\hline & & & & $<0.5$ \\
\hline & & storedQTX & & $<0.05$ \\
\hline \multirow[t]{4}{*}{768} & 3.9 & DTECH & $<5$ & $5-15$ \\
\hline & & OHM & & $<0.07$ \\
\hline & & & & $<0.05$ \\
\hline & & storedQTX & & $<0.05$ \\
\hline \multirow[t]{4}{*}{770} & 5.3 & DTECH & $5-15$ & $5-15$ \\
\hline & & $\mathrm{OHM}$ & & $<0.07$ \\
\hline & & EG & & $<0.5$ \\
\hline & & storedQTX & & $<0.05$ \\
\hline \multirow[t]{3}{*}{772} & 4.7 & DTECH & $5-15$ & $<5$ \\
\hline & & $\mathrm{OHM}$ & & $<0.07$ \\
\hline & & $\mathrm{EG}$ & & $<0.5$ \\
\hline \multirow[t]{3}{*}{774} & - & DTECH & $5-15$ & $5-15$ \\
\hline & & $\mathrm{OHM}$ & & $<0.07$ \\
\hline & & EG & & $<0.5$ \\
\hline \multirow{2}{*}{\multicolumn{2}{|c|}{ Lab blank }} & DTECH & $<5$ & $<5$ \\
\hline & & OHM & & $<0.07$ \\
\hline \multirow[t]{3}{*}{ Field blank } & & DTECH & $<5$ & $<5$ \\
\hline & & $\mathrm{OHM}$ & & $<0.07$ \\
\hline & & EG & & $<0.5$ \\
\hline BEW5 & - & $\mathrm{OHM}$ & 82 & 0.39 \\
\hline BEW6 & - & OHM & 852 & 1.36 \\
\hline
\end{tabular}

pared with a predicted $1 / 100$ value of the RP-HPLC determination and the data regressed, the accuracy is better (Fig. 5). The scatter in the data is then more obvious. The RPD criterion was met $100 \%$ of the time. This was the only kit tested that produced no false positives at its detection limit.

\section{EnviroGard}

The EnviroGard kit is also intended as a quantitative laboratory assay. The EnviroGard kit requires only a strip-reader for quantitation. A plate-shaker is listed as optional, as are platewashers and wash buffers other than tap water. One vial of TNT standard concentrate is supplied and must be diluted to make the suggested three standards. A negative control is supplied. The manufacturer recommends that absorbances be normalized against the negative control and expressed as a percent inhibition $\left(\% B / B_{0}\right.$, where $B=$ absorbance of sample and $B_{\mathrm{o}}=$ absorbance of negative control). The calculation of five standard curves produced a relative standard deviation of slopes equal to $4.0 \%$ (Fig. 6). A negative control and one standard would probably suffice for routine tests. The calculated concentrations were low compared with the RP-HPLC concentrations of 


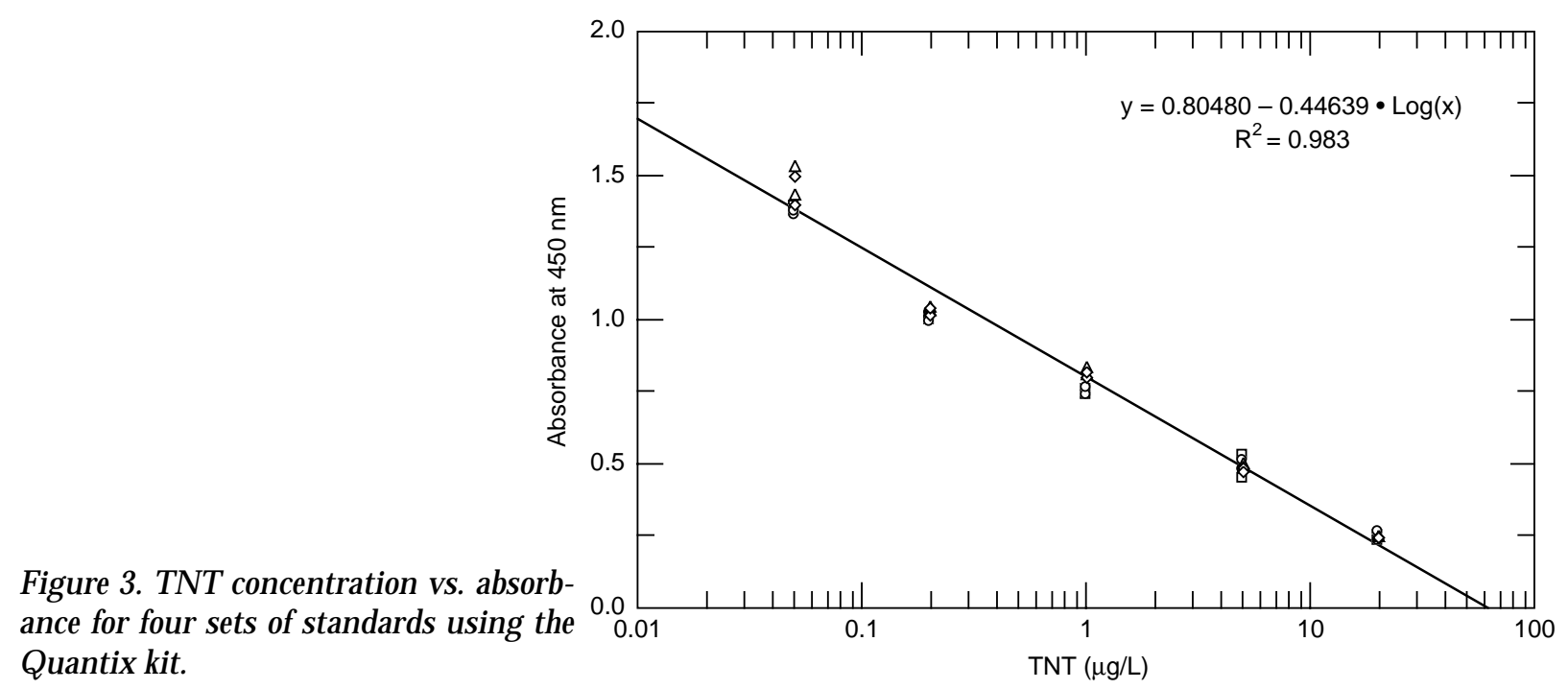

Figure 4. RP-HPLC values vs. average Quantix values.

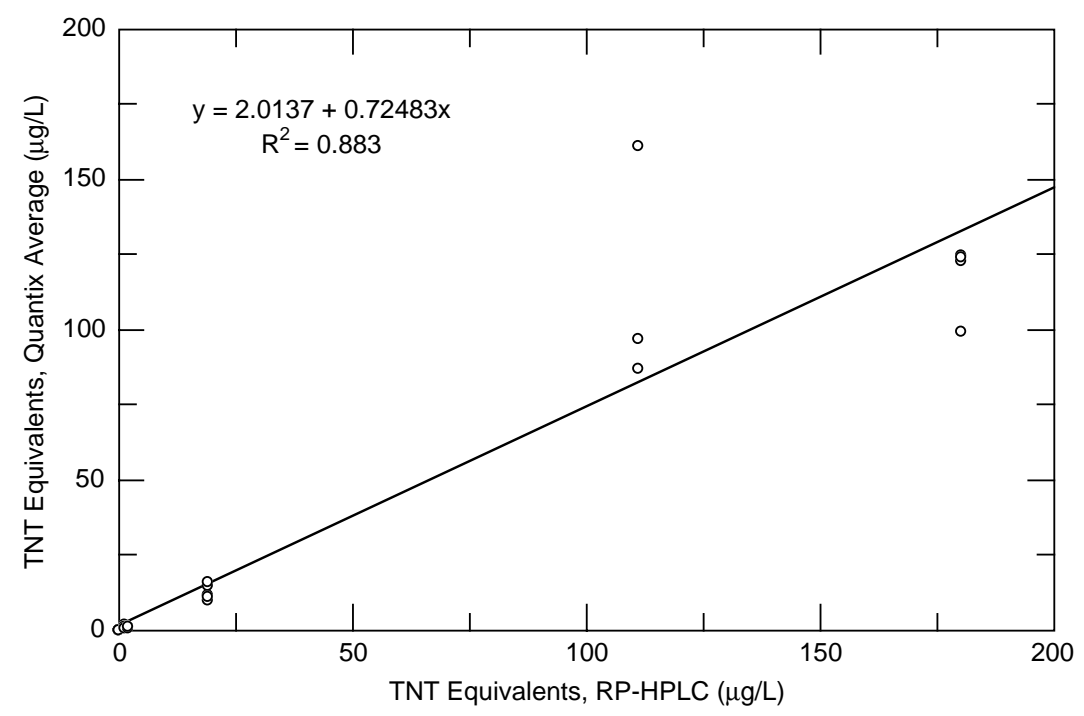

Figure 5. RP-HPLC values vs. all within-range Quantix values

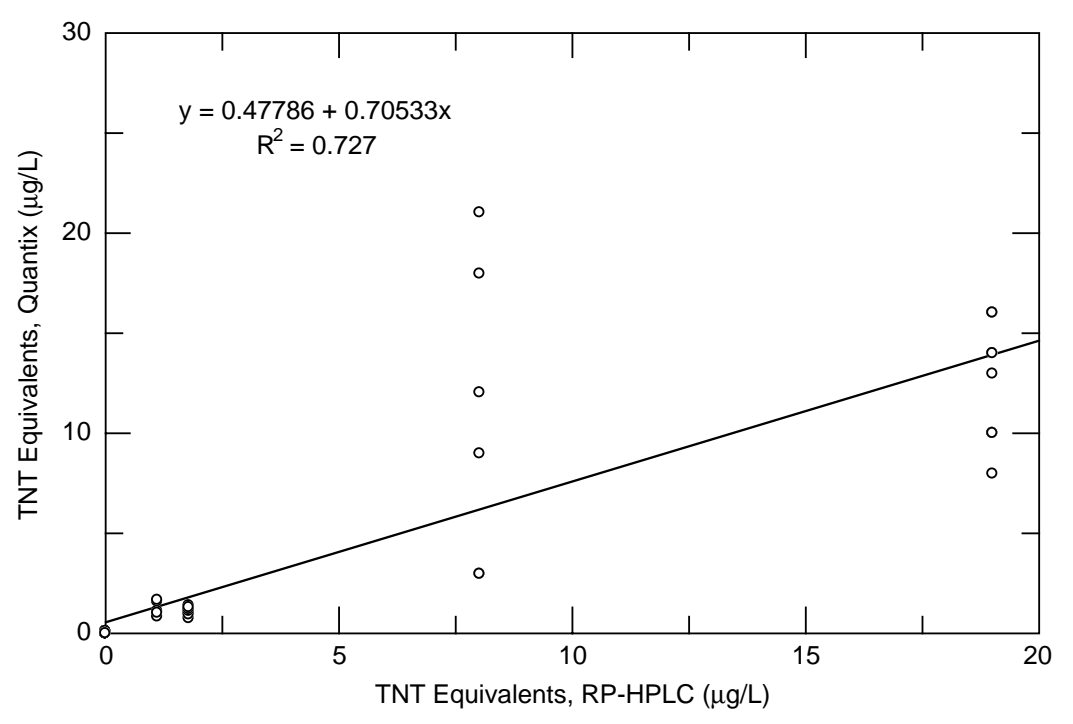



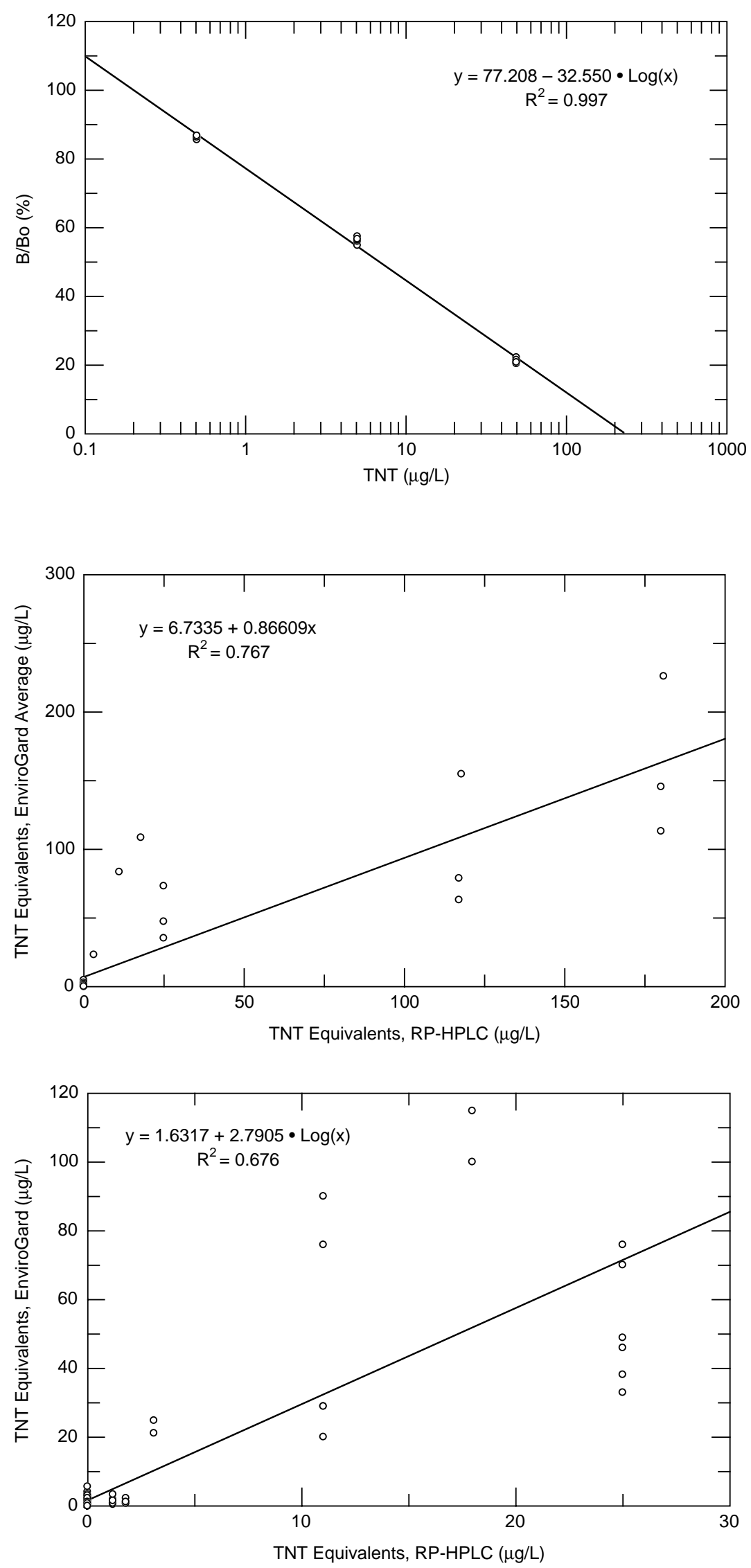

Figure 6. EnviroGard TNT plate kit: five sets of standards.

Figure 7. RP-HPLC values vs. average EnviroGard values.

Figure 8. RP-HPLC values vs. all within-range EnviroGard values. 
Figure 9. Ohmicron: three sets of standards.

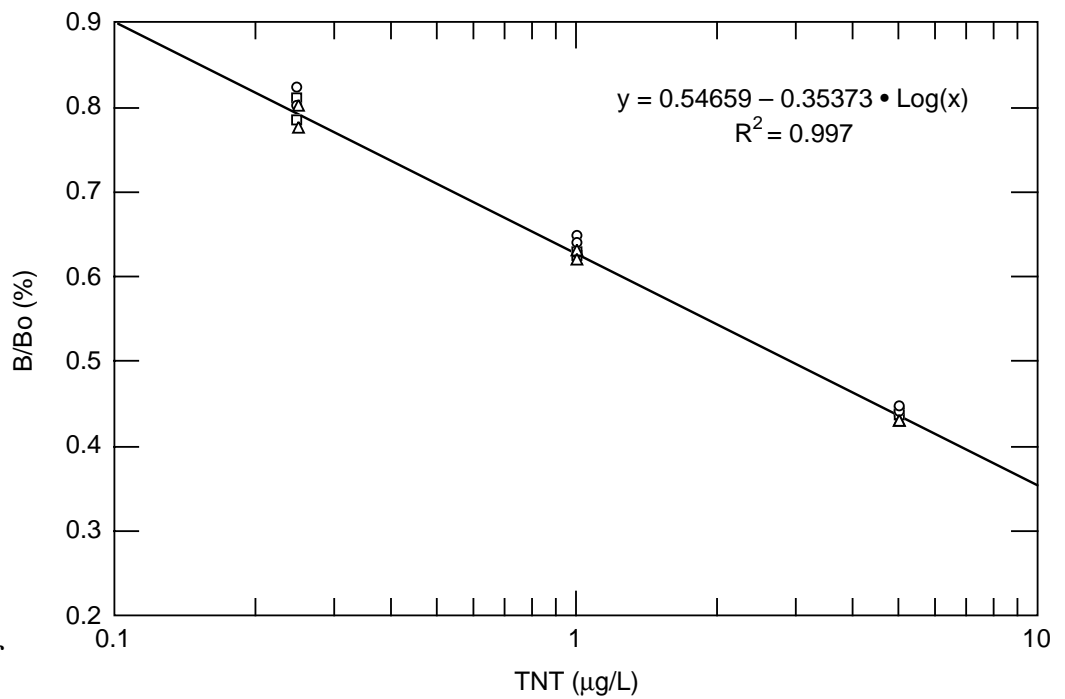

位

Figure 10. RP-HPLC values vs. Ohmicron average values.

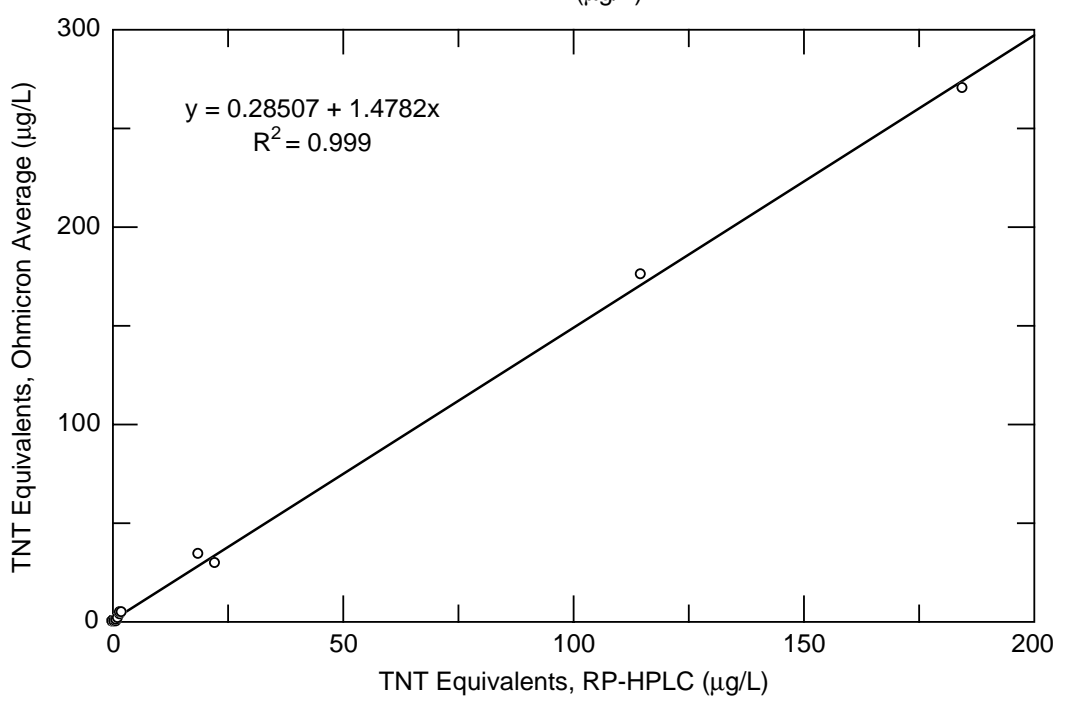

TNT when the regressed comparison extended to the three samples that needed dilution to fall within the range of the kit (Fig. 7). The RPD criterion was met $86 \%$ of the time. An examination of the individual values produced within the range of the kit (Fig. 8) shows a large overestimation. This overestimation of concentrations produced two false positives. These samples did however contain several $\mu \mathrm{g} / \mathrm{L}$ of TNT transformation products. If there are eight or more samples a day to analyze, this kit is the least expensive to use; however, the cost of false positives must be carefully considered.

Millipore also offers a TNT in Soil kit that uses test tubes and a standard spectrophotometer for quantitation. Since its detection limit is around 2 $\mu \mathrm{g} / \mathrm{L}$, it is not offered for sale as a water test kit. *

\section{Ohmicron RaPID assay}

The Ohmicron kit is intended to be a quantita- tive replacement for Method 8330 RP-HPLC determination. It includes a negative control, prediluted standards, and a check solution, whose value should lie within a range of accuracy in order to proceed with the test. Three calibration curves based on the percent inhibition compared with the negative control had a relative standard deviation of slopes equal to $3.4 \%$ (Fig. 9). A comparison between the RP-HPLC concentrations and the average calculated values and all of the within-range, diluted values (Fig. 10 and 11) shows that this kit overestimated the level of contamination. The RPD criterion was met $85 \%$ of the time. No false positives occurred above the $2-\mu \mathrm{g} / \mathrm{L}$ level. Three of the Crane wells that required dilution to fall within the range of the kit were assayed at two different dilutions. When the slopes of these serial

* Personal communication, B. Furgeson, Immunosystems, Scarboro, Maine, 1994. 

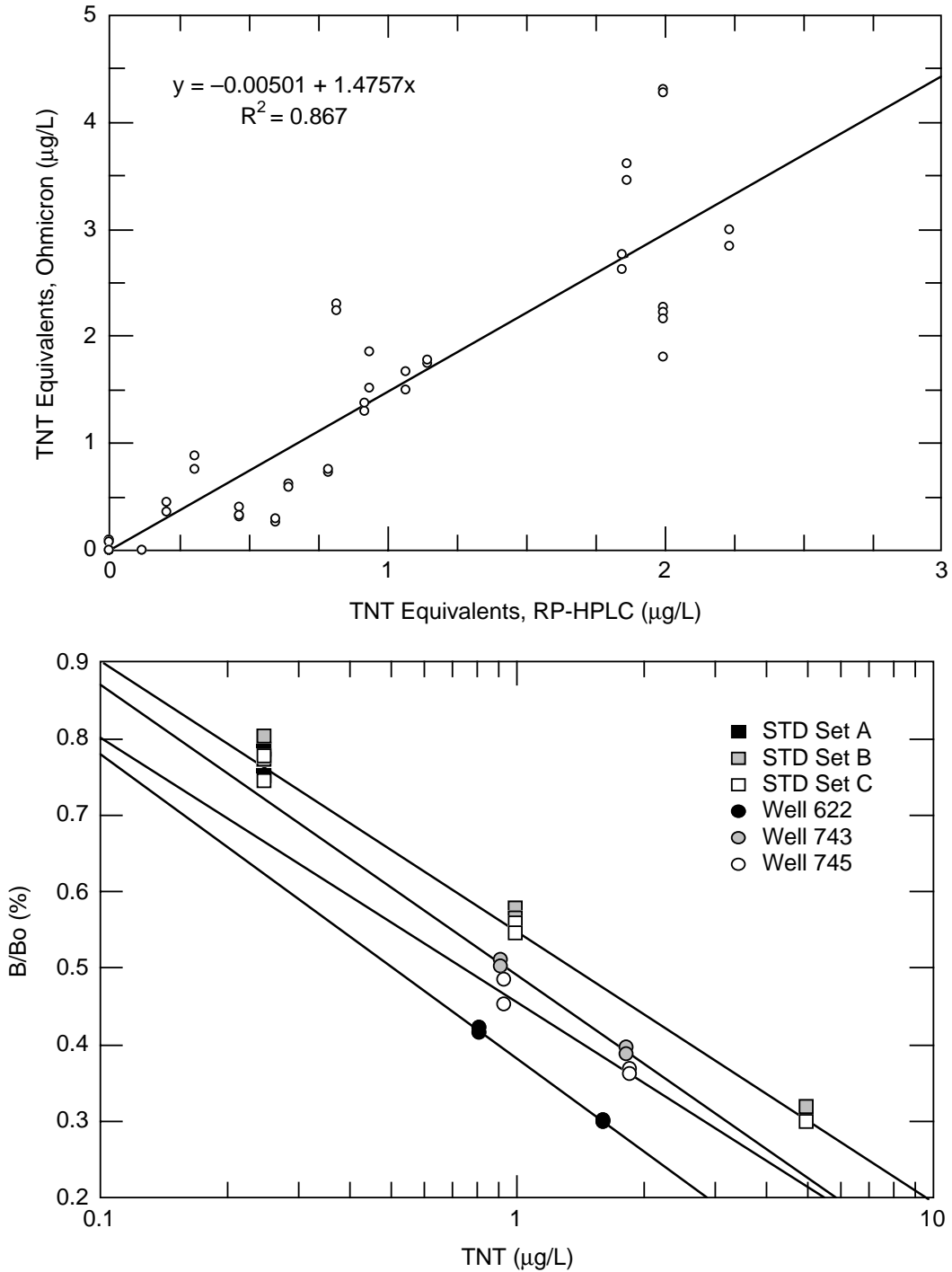

Figure 11. RP-HPLC values vs. all within-range Ohmicron values.
Figure 12. Serial dilutions of well water compared with standard curve. dilutions are compared with the slope of the calibration curve (Fig. 12), little or no matrix effect was apparent. The wells from Umatilla and Bangor did appear to have a positive matrix interference. The most accurate determinations were achieved when samples required substantial dilution with deionized water to fall within the range of the kit. The largest deviations from RPHPLC values occurred when samples were analyzed without dilution. The cost of this kit is intermediate and could be lowered approximately $50 \%$ by buying the assay tubes in bulk and running only one standard and one negative control each assay.

\section{DTECH}

The DTECH kits are small and completely selfcontained field kits. The materials for four samples could be carried in a large coat-pocket. They do not include provisions for producing a stan- dard curve. Each test runs with its own reference standard to mark the end-point of the color development. Duplicate analyses require another matching reference standard. They also produce the quickest analyses: 10 minutes vs. 45 to 90 minutes for the other kits. The use of concentration ranges for quantitation emphasizes the qualitative nature of the analyses. Although not required, a TNT standard curve was produced using the numerical values from the reflectometer (Fig. 13). The standard curve published with the kit is quite different. The accuracy and precision of the analyses are plotted with references to the ranges specified on the color card and reflectometer conversion chart. In all cases, the reflectometer and color card agreed. The ranges are filled in with frequency of occurrence values (Fig. 14). Except for one value in the $25-45-\mu \mathrm{g} / \mathrm{L}$ range, the kit overestimated the RP-HPLC values. Multiplying the range as detected by the dilution factor produced 
Figure 13. Standard curve produced at

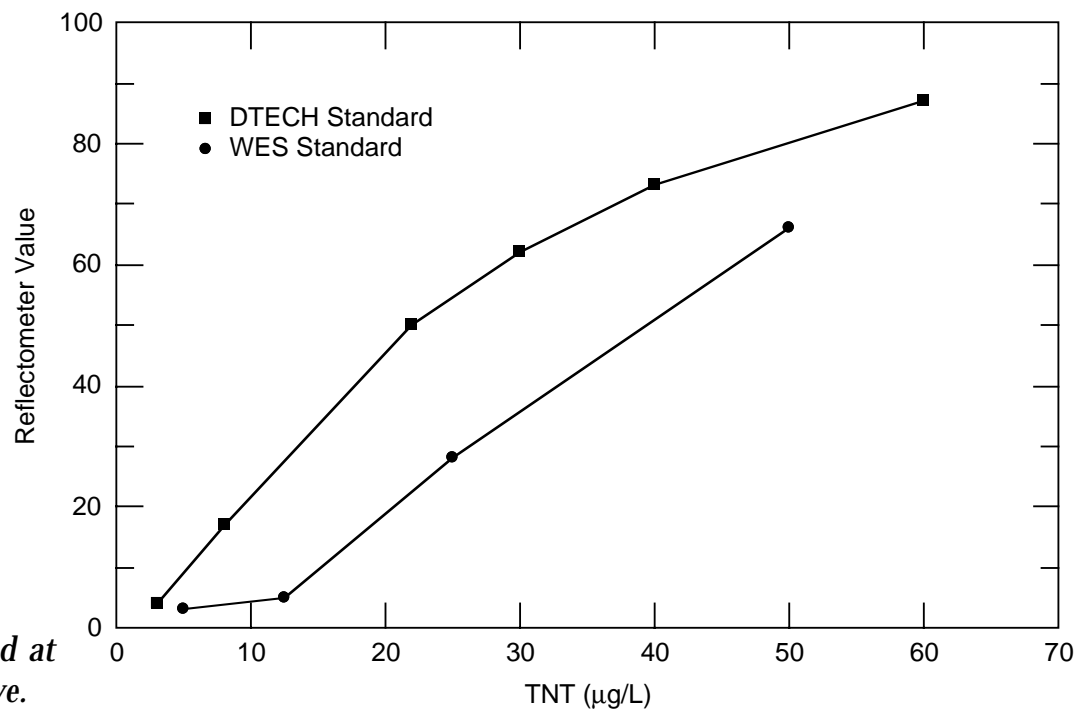
WES vs. the DTECH published curve.

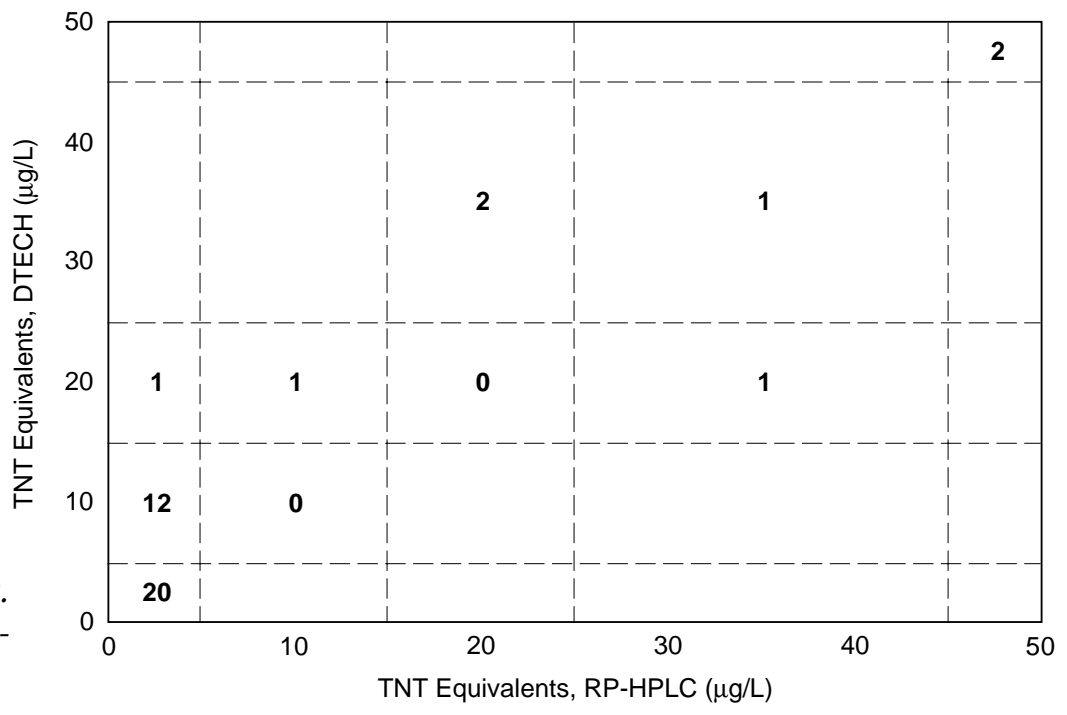

Figure 14. RP-HPLC values vs. DTECH values. Frequency of occurrence within each range.

The RDX kit performed so poorly that the manthe extreme high values for wells 731 and 743 (Table 3). The RPD criterion had to be redefined; it was acceptable if the kit value and RP-HPLC value fell within the same range. These kits failed that test over half the time. The TNT kit produced the highest number of false positives-10 out of 33 wells. The question of false negatives can be answered in two ways. The detection limit claimed by the kit is $5 \mu \mathrm{g} / \mathrm{L}$, ten times higher than the next most sensitive kit (EnviroGard). At this level no false negatives occurred. However, the lack of false negatives is offset by the fact that the detection limit of $5 \mu \mathrm{g} / \mathrm{L}$ is higher than the $2 \mu \mathrm{g} / \mathrm{L}$ health advisory value proposed by the EPA for drinking water (EPA 1989). The kit did fail to detect TNT or its cross-reactive transformation products in nine samples that had measurable quantities by RP-HPLC. These kits might be considered when the detection limit is adequate and the cost of false positives is low. ufacturer was contacted for advice. ${ }^{*}$ Other than a color development more rapid than anticipated, the kits passed the manufacturer's quality control standards. Attempts to create a standard curve, as was done for TNT, were unsuccessful.

\section{SUMMARY AND CONCLUSIONS}

The results of this investigation of 44 groundwater wells were disappointing. None of the test kits performed as well as advertised. The quantitative assays were neither accurate nor precise enough to replace Method 8330 RP-HPLC determinations, although they can be used adequately as screening tools. Of the two DTECH assays, the RDX test failed badly by producing eight false

* Personal communication, G.Teaney, Strategic Diagnostics, Newark, Del., 1994. 
negatives and six false positives. The TNT test produced ten false positives. Both of the DTECH kits had detection limits above the EPA health advisory limits.

The poor accuracy may be due to nonspecific matrix effects as indicated by the differences between performance of within-range and average values. It is also possible that the cross reactivities of the transformation products, which were identified in these samples by RP-HPLC, are different from the values quoted by the manufacturers. There could be chemicals in the wells that cause an antibody response that were not tested by the manufacturers and do not appear in the Method 8330 analysis. The poor precision may have been caused by heterogeneously distributed suspended or colloidal material. None of the kits requires filtration of water samples. At the time of analysis, most of the suspended material had settled; however, a few tests were done with samples that had been agitated and were quite turbid. The results from these tests were within the range of the results from the clear samples. The most precise kit, evaluated using the 2- $\mu \mathrm{g} / \mathrm{L}$ EPA health advisory limit, was the Quantix, which had the most rigorous wash procedure. It uses a detergent solution and an aspirated plate-washer.

Improvements in the precision of the Ohmicron kit might be obtained by vortexing the antibody particles in the supplied detergent solution rather than merely rinsing the cluster that formed on the test tube walls next to the magnetic separator. Additional time would be required to redeposit the vortexed particles after each rinse. The precision of the EnviroGard kit might be improved by substituting a detergent solution for the recommended tap-water rinse. Improved washing steps might also improve the accuracy if positive interferences were nonspecific.

\section{FURTHER TESTS AND CURRENT STATUS}

As this report was going to press, results from a second evaluation became available (Craig et al. 1996). Well water from Umatilla Army Depot Activity, Hermiston, Oregon, and well water and soil-washing leachate from the U.S. Naval Submarine Base, Bangor, Washington, were tested using the DTECH (TNT and RDX) and Ohmicron (TNT) immunoassays, prototype antibody-based biosensors (TNT and RDX) from the Naval Research Laboratory (NRL), and EnSys colorimetric kits (TNT and RDX). Problems encountered with the DTECH RDX kit were not repeated here. DTECH supplied improved operating methods for their reflectometer that quantified the color-development time. In addition, the development time was closer to the expected 5 minutes. The results of this comparison showed that the colorimetric methods had the greatest accuracy, followed by the NRL biosensors, then the immunoassays. The accuracy of the immunoassays and biosensors were better at Umatilla than at Bangor. The high organic content and turbidity of the Bangor waters probably contributed nonspecific interferences. When contaminant levels were higher than the test ranges and the samples required dilution with distilled water, the accuracy of the immunoassays and biosensors was better. The colorimetric method involves a solid-phase extraction step, minimizing the contribution of the sample matrix.

In addition, the commercial immunoassay market made a major transition. The Quantix company has been bought out twice and the kit we used is no longer available. Ohmicron, EnviroGard, EnSys, and DTECH were combined as Strategic Diagnostics, Inc. At this time, all of their kits are available; however, it is expected that only one or two products will emerge as long-term replacements for the four existing formats.

\section{LITERATURE CITED}

Craig, H., G. Ferguson, A. Markos, A. Kusterbeck, L. Shriver-Lake, T. Jenkins, and P. Thorne (1996) Field demonstration of on-site analytical methods for TNT and RDX in ground water. In Proceedings of the HSRC/WERC Joint Conference on the Environment, Albuquerque, New Mexico, May 21-23, 1996. Las Cruces: New Mexico State University, p. 204-219. EPA (1988a) Health advisory for RDX. Office of Drinking Water. Washington, D.C.: U.S. Environmental Protection Agency.

EPA (1988b) Health advisory for HMX. Office of Drinking Water. Washington, D.C.: U.S. Environmental Protection Agency.

EPA (1988c) Health advisory for 1,3-dinitrobenzene. Office of Drinking Water. Washington, D.C.: U.S. Environmental Protection Agency.

EPA (1989) Trinitrotoluene health advisory. Office of Drinking Water, Washington, D.C.: U.S. Environmental Protection Agency.

EPA (1992) Dinitrotoluene health advisory. Criteria and Standards Division, Office of Drinking Water. Washington, D.C.: U.S. Environmental Protection Agency.

EPA (1994) Nitroaromatics and nitramines by high 
performance liquid chromatography. SW846 Method 8330, November. Washington, D.C.: U.S. Environmental Protection Agency.

Jenkins, T.F., and M.E. Walsh (1992) Development of field screening methods for TNT, 2,4-DNT and RDX in soil. Talanta, 39: 419-428.

Jenkins, T.F., P.G. Thorne, and M.E. Walsh (1994) Field screening method for TNT and RDX in groundwater. USA Cold Regions Research and Engineering Laboratory, Special Report 94-14.

Keuchel, C., L. Well, and R. Niessner (1992a) Effect of the variation of the length of the spacer in a competitive enzyme immunoassay (ELISA) for the determination of 2,4,6-trinitrotoluene (TNT). Freseius Journal of Analytical Chemistry, 343: 143.

Keuchel, C., L. Well, and R. Niessner (1992b) Enzyme-linked immunosorbent assay for the determination of 2,4,6-trinitrotoluene and related nitroaromatic compounds. Analytical Science, 8: 9-12.
Keuchel, C., L. Well, and R. Niessner (1992c) Development of an enzyme immunoassay for the determination of 2,4,6-trinitrotoluene-Probing the influence of humic acids. International Society for Optical Engineering (SPIE), 1716: 44-50.

Vanderlaan, M., L. Stanker, and B. Watkins (1990) Immunochemical techniques in trace residue analysis. In Immunoassays for Trace Chemical Analysis (M. Vanderlaan, L.H. Stanker, B.E. Watkins, and D.W. Roberts, Ed.). Symposium Series 451. Washington, D.C.: American Chemical Society, p. 2-12.

Walsh, M.E., T.F. Jenkins, P.S. Schnitker, J.W. Elwell, and M.H. Stutz (1993) Evaluation of SW846 Method 8330 for characterization of sites contaminated with residues of high explosives. USA Cold Regions Research and Engineering Laboratory, CRREL Report 93-5. 


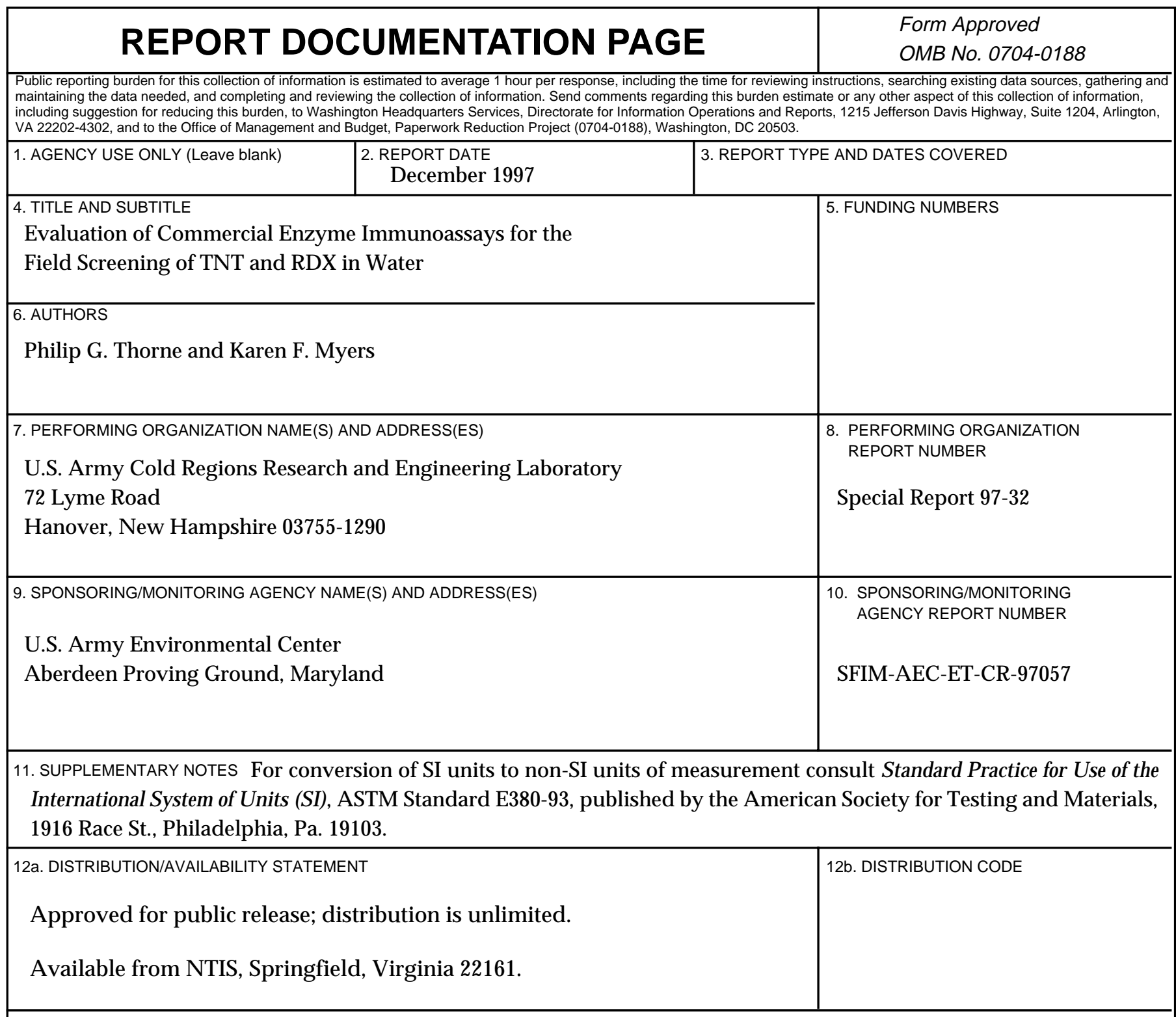

13. ABSTRACT (Maximum 200 words)

Water samples from 44 monitoring wells at three military installations were analyzed for the high explosives TNT and RDX using immunoassay test kits. The accuracy and precision of the kit determinations were compared with results obtained using the RP-HPLC, EPA Method 8330 . Most of the kits achieved a $\pm 50 \%$ relative percent difference criterion over $85 \%$ of the time. One of the kits failed this test over half the time. Careful consideration must be given to interferences that may be present and unique for each application.

\begin{tabular}{|c|c|c|c|c|}
\hline \multirow{2}{*}{$\begin{array}{l}\text { 14. SUBJECT TERMS } \\
\text { Chemical analysis } \\
\text { Environmental impact } \\
\text { Explosives }\end{array}$} & \multirow{2}{*}{$\begin{array}{l}\text { Groundwater } \\
\text { Military research } \\
\text { TNT }\end{array}$} & \multirow{2}{*}{\multicolumn{2}{|c|}{$\begin{array}{l}\text { RDX } \\
\text { Water pollution }\end{array}$}} & $\begin{array}{c}\text { 15. NUMBER OF PAGES } \\
20\end{array}$ \\
\hline & & & & 16. PRICE CODE \\
\hline $\begin{array}{l}\text { 17. SECURITY CLASSIFICATION } \\
\text { OF REPORT }\end{array}$ & $\begin{array}{l}\text { 18. SECURITY CLASS } \\
\text { OF THIS PAGE }\end{array}$ & ATION & $\begin{array}{l}\text { 19. SECURITY CLASSIFICATION } \\
\text { OF ABSTRACT }\end{array}$ & 20. LIMITATION OF ABSTRACT \\
\hline UNCLASSIFIED & UNCLASSII & & UNCLASSIFIED & $\mathrm{UL}$ \\
\hline
\end{tabular}

